\title{
O ESTÂNDAR NO BRASIL. UMA DISCUSSÃO SOBRE PLURICENTRISMO, CODIFICAÇÃO NORMATIVAE O PAPEL DA LEXICOGRAFIA
}

\author{
EL ESTÁNDAR EN BRASIL. UNA DISCUSIÓN SOBRE PLURICENTRISMO, \\ CODIFICACIÓN NORMATIVA Y EL PAPEL DE LA LEXICOGRAFÍA
}

Virginia Sita Farias

Universidade Federal do Rio de Janeiro -UFRJ

virginiafarias@hotmail.com

Resumo: O pluricentrismo - como questão fundamentalmente político-ideológica está intimamente relacionado com a estandardização linguística e, por conseguinte, com a codificação normativa. No âmbito lusófono - em comparação, por e xemplo, com o hispanófono ou o francófono, por um lado, e com o anglófono, por outro -, muito embora tenha se desenvolvido uma "consciência pluricêntrica", esta não se reflete na elaboração das principais obras de referência (gramáticas e dicionários), seja aquém ou além-mar. O objetivo do presente artigo é, portanto, discutir o problema da fixação do estândar e da codificação normativa do português no Brasil, em comparação com outras línguas de cultura. Aênfase recairá no tipo de codificação proposta nos dicionários gerais brasileiros (supranacional monocêntrica, supranacional pluricêntrica ou nacional stricto sensu), afim de aferir (i) sua coerência do ponto de vista metalexicográfico e (ii) o êxito real obtido na consecução dos respectivos projetos. Palavras-chave: (Meta)lexicografia; Estândar; Pluricentrismo; Codificação normativa.

Resumen:Elpluricentrismo-comocuestión fundamentalmentepolítico-ideológica está en estrecha relación con la estandarización y, por ende, la codificación normativa. En el ámbito lusófono -en comparación, por ejemplo, con el hispanófono o el francófono, por una parte, y el anglófono, por otra, aunque se haya desarrollado una suerte de "consciencia pluricéntrica”, ésta no se ve reflejada en la elaboración de las principales obras de referencia (gramáticas y diccionarios) a uno y otro lado delAtlántico. Así pues, el objetivo que se plantea en el presente artículo es discutir el problema de la fijación del estándar y la codificación normativa del portugués en Brasil, en comparación con otras lenguas de cultura. El énfasis será puesto en el tipo de codificación propuesto en los diccionarios generales brasileños (supranacional monocéntrica, supranacional pluricéntrica o nacional stricto sensu), con el fin de evaluar (i) su coherencia desde el punto de vista metalexicográfico y (ii) el grado de éxito que se ha logrado en la consecución de los respectivos proyectos. Palabras clave: (Meta)lexicografia; Estándar; Pluricentrismo; Codificación normativa. 


\section{Português como língua pluricêntrica: uma perspectiva comparada ${ }^{1}$}

Oconceito de pluricentrismo, embora, evidentemente, também tenha consequências no plano linguístico, é, em princípio, produto direto de uma construção discursivo-ideológica razão pela qual defini-lo, segundo Kailuweit (2015), ainda hoje, meio século após seu surgimento e início de sua disseminação, sobretudo no âmbito da linguística europeia (cf. STEWART, 1968; KLOSS, 1967; 1978; CLYNE, 1992d; MUHR, 2012), não é tarefa simples.

Nesse sentido, Heger (1993), por exemplo, em sua resenha de Clyne (1992d), já alertava para a falta de consenso, entre os autores dos dezessete artigos reunidos na referida obra, sobre a ideia de pluricentrismo/língua pluricêntrica. Como consequência, em alguns dos estudos aí publicados, verifica-se uma confusão entre os conceitos de variedade nacional/ estândar ${ }^{2}$ e variedade regional/dialeto. Nem mesmo o próprio editor da obra ficou imune: em seu artigo acerca do pluricentrismo no âmbito germânico (cf. CLYNE, 1992c), refere-se a algumas variedades (estândares) do alemão como regionais ("regional South German"). Tais problemas persistem até a atualidade devido, em grande parte, à tentativa de se definir em termos estritamente linguísticos (cf., por exemplo, OESTERREICHER, 2000; 2002) categorias como mono e pluricentrismo, que são, em essência, conforme Zimmermann (2018), glotopolíticas.

Em linhas gerais, e ainda que diversificação e fragmentação, inclusive no nível terciário, ${ }^{3}$ sejam uma constante na história das línguas naturais, a consciência pluricêntrica de uma dada comunidade linguística costuma desenvolver-se concomitantemente à implementação de políticas (intra)linguísticas ${ }^{4}$ que visam à fixação e difusão de estândares "nacionais" (cf. LEBSANFTe TACKE, 2020). ${ }^{5}$ Essas políticas, explícitas ou tácitas, levadas a cabo em etapas que podem prolongar-se por várias décadas, originam-se, via de regra, como resposta à reivindicação por uma "língua nacional", em especial no caso de idiomas

1 Uma primeira versão deste estudo foi apresentada em outubro de 2017 no VI Simpósio Mundial de Estudos da Língua Portuguesa (SIMELP), Santarém/Portugal, na forma de uma comunicação intitulada "Português língua pluricéntrica e sua representação nos dicionários. A codificação normativa frente à descrição da variação linguística na lexicografia brasileira (em contraste com a lexicografia peninsular)". Esta versão preliminar foi revista, corrigida e ampliada a partir dos resultados obtidos durante o período de pós-doutorado realizado entre setembro de 2018 e abril de 2019 junto à Universität Paderborn/Alemanha, graças a uma bolsa outorgada pela Fundação Alexander von Humboldt em cooperação com a CAPES.

2 Sobre o conceito de variedade nacional, cf. Clyne (1989; 1992a); para uma revisão crítica da correlação estabelecida entre variedade nacional e estândar, cf. Heger (1989; 1993) e Farias (2020b).

3 Acerca da formação de dialetos terciários (ou línguas/normas exemplares), cf. Coseriu (1980; 1982; 1990; 2006); para uma visão crítica acerca da emergência de dialetos em diversos níveis, cf. Krefeld (2011b); sobre o problema da norma (exemplar) na linguística coseriana, cf. Kabatek (2020).

4 Bergenholtz e Tarp (2004) distinguem duas dimensões das políticas linguísticas: a interlinguística e a intralinguística. A primeira equivale à planificação do status [in. status planning; al. Sprachenpolitik], ao passo que a segunda corresponde à planificação do corpus [in. corpus planning; al. Sprachpolitik].

5 Esses estândares, em princípio "nacionais", podem, ocasionalmente, em determinadas circunstâncias (socio) históricas e políticas, que aqui não serão discutidas, chegar a funcionar "supranacionalmente", como parece ser o caso, por exemplo, do estândar mexicano (cf. OESTERREICHER, 2002).

Vol. 25 - Ano $44-n^{\circ} 2-2020$ 
como o inglês, o francês, o espanhol ou o português, transplantados a outros continentes como consequência de processos de conquista e colonização (cf. SCHNEIDER, 2003). É somente após a emergência dos chamados "estândares nacionais" que a questão do pluricentrismo pode, efetivamente, ser abordada do ponto de vista linguístico-descritivo: o surgimento de estândares divergentes leva à conformação de arquiteturas pluricêntricas e, por conseguinte, demanda a descrição dos respectivos espaços variacionais constituídos no âmbito das línguas históricas em questão. ${ }^{6}$

Posto o anterior, se os diversos estândares se relacionam de maneira mais ou menos simétrica (a esse respeito, cf. CLYNE, 1992b) e, além disso, estão devidamente codificados em gramáticas e dicionários, os problemas quanto ao reconhecimento do pluricentrismo costumam ser menores. Esse é o caso, por exemplo, do inglês, ao menos no que concerne às variedades britânica e americana, consideradas centrais (cf. CLYNE e SHARIFIAN, 2008). Asituação, no entanto, se complica quando se trata de definir o pluricentrismo, por exemplo, no âmbito das culturas linguísticas ${ }^{7}$ lusófona ${ }^{8}$, hispanófona ou francófona. A fragmentação terciária ocorrida nesses casos, decorrente da difusão espacial e consequente condição de língua nacional/oficial - e, portanto, língua de cultura - desses idiomas em diversos países, ${ }^{9}$ teve como resultado a emergência de estândares de diferentes pesos e alcances em cada caso. A isso se soma uma descrição incompleta das variedades nacionais americanas, africanas e, no caso do português, também asiáticas (cf. ad infra). Dessa forma, embora a condição pluricêntrica dessas três línguas seja discutida na literatura relativa ao temajá há várias décadas (acerca do português, cf. BAXTER, 1992; PÖLL, 2001; OLIVEIRA, 2016; SILVA, 2016; 2017; 2018a; 2018b; acerca do espanhol, cf. THOMPSON, 1992; BIERBACH, 2000; PÖLL 2001; 2012; OESTERREICHER, 2000; 2002; RIVAROLA, 2006; GREUSSLICH e LEBSANFT, 2020; e acerca do francês, cf. LÜDI, 1992; 2013; PÖLL, 2005), resta ainda um longo caminho a percorrer rumo ao reconhecimento da sua

6 A questão do pluricentrismo é tratada aqui do ponto de vista da linguística variacional de tradição alemã (a esse respeito, cf. LÓPEZ SERENA, 2013). Acerca dos conceitos de língua histórica, bem como de seus correlatos lingua funcional, diassistema e arquitetura, cf. Coseriu (1967; 1980; 1982; 2004) e Heger (1969); sobre os conceitos de espaço variacional, cadeia variacional e estândar, cf. Koch e Oesterreicher (2011), Oesterreicher (2000; 2002) e Koch (2009); por fim, para uma visão crítica acerca do conceito de estândar e dos problemas concernentes à sua localização na cadeia variacional de Koch e Oesterreicher, cf. Krefeld (2011a; 2018).

7 O termo cultura linguística - e seu correlato cultivo linguístico - correspondem, aqui, respectivamente, aos termos alemães Sprachkultur e Sprachpflege (cf. LEBSANFT, 1997). Destaca-se, porém, que os equivalentes propostos não possuem as mesmas conotações que têm em alemão e tampouco se encontram arraigados no âmbito das tradições metalinguísticas de língua portuguesa.

8 O adjetivo lusófono - assim como o substantivo lusofonia - são utilizados aqui no seu sentido mais "neutro", por assim dizer, considerando as definições que os dicionários de língua portuguesa proporcionam para cada um dos vocábulos: lusófono "que se utiliza do português como língua de cultura" (DUPB, 2002, s.v.) e lusofonia "adoção do português como língua de cultura" (DUPB, 2002, s.v.). Acerca das polêmicas que envolvem o conceito de lusofonia, cf. Faraco (2012).

9 Sobre a difusão espacial do português e as características da cultura linguística correspondente, cf. SchmidtRadefeldt (2002); acerca do espanhol, cf. Lebsanft (1997; 2002), e do francês, cf. Pöll (2017).

Vol. $25-$ Ano $44-n^{\circ} 2-2020$ 
pluralidade normativa do ponto de vista político-ideológico e, sobretudo, da sua comprovação do ponto de vista linguístico-descritivo.

No que diz respeito ao espanhol, é inegável o avanço que representou, do ponto de vista político-ideológico, sua (aparente) aceitação no documento intitulado La Nueva Política Lingüística Panhispánica (NPLP, 2004), redigido pela Real Academia Española (RAE) em conjunto com a Asociación de Academias de la Lengua Española (ASALE). Entretanto, do ponto de vista linguístico-descritivo, a condição pluricêntrica do espanhol ainda não pode ser considerada um fato empiricamente comprovável (cf. GREUSSLICH, 2015; FARIAS, 2019a; GREUSSLICH e LEBSANFT, 2020): embora a diversificação terciária do espanhol na América tenha redundado na constituição de diversas normas cultas de alcance local, nacional ou supranacional, estas, por razões históricas e, sobretudo, políticas, ainda não estão bem discriminadas (cf. RIVAROLA, 2006; LÜDTKE, 2007) e, consequentemente, não atingiram o mesmo prestígio de que goza o estândar peninsular (cf. PÖLL, 2001, p.920 ss.). Isso levou a que o pluricentrismo da cultura linguística hispânica fosse caracterizado, hoje, por uma visível assimetria (cf. PÖLL, 2012; LEBSANFT, MIHATSCH e POLZINHAUMANN, 2012). A assimetria do espanhol, no entanto, não é tão acentuada quanto a do francês, cuja academia, marcada por uma atuação historicamente purista, colaborou de modo intenso para a manutenção do prestígio do estândar europeu e, por conseguinte, de sua (quase) indiscutível centralidade no âmbito francófono (cf. PÖLL, 2012).

A situação do português - cujo pluricentrismo é considerado mais simétrico em comparação com o espanhol ou o francês - é um pouco diferente. Se, por um lado, do ponto de vista histórico-ideológico, as condições da colonização e implementação/difusão do português no Brasil tenham contribuído enormemente para o desenvolvimento de uma consciência (etno)linguística que tende à dissociação total entre o português brasileiro (PB) e o europeu (PE) (cf. FARIAS, 2020c), por outro lado, do ponto de vista das políticas linguísticas, esses mesmo fatores, paradoxalmente, não favoreceram a consecução deum projeto de estandardização independente. Neste ponto, deve-se considerar, em primeiro lugar, que as discussões em torno ao problema da normatização linguística no Brasil costumam centrar-se nas divergências (sistêmicas ou não) entre o PB e o PE (cf., por exemplo, TARALLO, 1993; CASTILHO, 2008). Como consequência direta, o foco das descrições (socio)linguísticas costumam ser, justamente, as variedades vernáculas do $\mathrm{PB}$, pois é nesse âmbito que as divergências tendem a ser mais evidentes (cf. DUARTE, GOMES e PAIVA, 2016). Em segundo lugar, a delimitação e fixação do estândar no Brasil são tratadas, em geral, como questões restritas ao plano político-ideológico, que, sem sombra de dúvida, é de suma importância. O problema, porém, reside em abster-se, muitas vezes, de prestar a devida atenção às dimensões social e sistêmico-linguística (cf. 2.1) da estandardização (cf. ZANATTA, 2009; FARIAS, 2011; 2019b). 
Com relação à estandardização, cabe ainda destacar que uma de suas etapas fundamentais é a codificação (cf. HAUGEN, 1983) - que, aliás, por si só, em vista do exposto nos parágrafos precedentes, já seria uma questão espinhosa. Em se tratando especificamente de culturas linguísticas caracterizadas pela pluralidade de normas exemplares, para empregar os termos coserianos, o reconhecimento efetivo do pluricentrismo do ponto de vista políticoideológico está atrelado, em grande medida, como recorda Rivarola (2001), à descrição - e codificação - dos respectivos estândares. Não obstante, tanto no caso do português como no do espanhol ou do francês, a pluralidade normativa das culturas linguísticas em questão não é corroborada pela codificação sistemática das respectivas variedades.

Aqui se abordará o problema da codificação normativa do ponto de vista (meta) lexicográfico. Nesse contexto, o dicionário pode converter-se em uma importante ferramenta das políticas (intra)linguísticas, posto que participa ativamente no processo de fixação do estândar (cf. CORREIA e FERREIRA, 2013), assumindo, dessa forma, um papel primordial no que se refere ao desenvolvimento da cultura e do cultivo linguístico (cf. BERGENHOLTZ, 2006).

No que concerne ao espanhol, destaca-se a carência de dicionários integrais destinados à descrição das variedades nacionais americanas. ${ }^{10}$ Assim sendo, a codificação pluricêntrica/ pan-hispânica que a RAE em cooperação com a ASALE propõe nas obras de referência publicadas posteriormente à divulgação da $N P L P$ - ainda que, na prática, diste muito de representar a realidade linguística do espanhol (cf. GREUSSLICH, 2015; FARIAS, 2018a; 2018 b) - preenche parcialmente a "lacuna normativa" existente na cultura linguística hispânica (cf. FARIAS, 2019a; 2020a). O caso do inglês, por outro lado, é oposto ao do espanhol: a tradição lexicográfica americana começou a consolidar-se frente à britânica ambas, deve-se recordar, desvinculadas de academias - já em meados do século XIX (cf. LANDAU, 2001, p.43-97; LARA, 1996, p.47-66). Esse fato contribuiu, seguramente, não só para a constituição/o fortalecimento de uma identidade (etno)linguística nos Estados Unidos, mas também para a configuração de um pluricentrismo mais equilibrado.

No caso do português, a situação, uma vez mais, diverge das anteriores. Destacase, em primeiro lugar, a ausência de uma instituição normativa centralizadora como a $\mathrm{RAE}^{11} \mathrm{e}$, por conseguinte, conforme destacam Correia e Ferreira (2013), a inexistência de

10 De acordo com Lara (2015, p. 29-31), os projetos que visavam à elaboração de dicionários integrais na América surgiram com o intuito de opor-se aos dicionários diferenciais - muito difundidos no âmbito da lexicografia americana de língua espanhola e um dos principais traços característicos dessa tradição lexicográfica (a esse respeito, cf. ZIMMERMANN, 2018). Lamentavelmente, até o momento, apenas dois projetos foram concluídos: o mexicano, que resultou na publicação, primeiramente, do Diccionario del español usual en México (DEUM, 1996) e, posteriormente, do Diccionario del español de México (DEM, 2010), e o argentino, que culminou com a publicação do Diccionario integral del español de la Argentina (DIEA, 2008). Com a conclusão de todos os projetos - ou pelo menos de uma parte considerável deles -, seria possível descrever de maneira mais precisa - ao menos no nível lexical - a situação do pluricentrismo no mundo hispanófono. 
instrumentos de codificação "panlusitanos" - por analogia ao termo castelhano panhispánico. Em segundo lugar, também é preciso considerar que as comunidades lusófonas só muito tardiamente, em comparação com outras línguas de cultura, começaram a discutir a questão da normatização linguística' ${ }^{12}$ e da constituição de exemplaridades autóctones (cf. FIORIN, 2014; ANTUNES, 2014). No caso da linguística brasileira, deve-se acrescentar, ademais, que as discussões sobre a norma padrão - que têm entre seus principais expoentes Bagno (2001; 2012) e Lucchesi (2012) - costumam basear-se no argumento do poder coercitivo do estândar. Não é raro, pois, conforme o exposto em FARIAS (2011;2019b), que se chegue a questionar, inclusive, a real necessidade de se fixar uma norma exemplar para o PB. Por último, o panorama esboçado ad supra poderia ser considerado como causa e produto, concomitantemente, do relativo atraso da produção lexicográfica de língua portuguesa em relação com outras línguas de cultura (cf. PÖLL, 1996). Essas são algumas das razões pelas quais, não obstante se dê por sentado o bicentrismo ${ }^{13}$ mais ou menos simétrico da cultura linguística lusófona do ponto de vista político-ideológico, há uma lacuna histórica com relação à fixação e codificação de um estândar brasileiro (cf. FARIAS, 2020c). Dessa forma, diante da rejeição - absolutamente compreensível, deve-se deixar claro - tanto ao estândar europeu (cf. FARACO e ZILLES, 2017, p.168; FARACO, 2019, p.118) quanto à norma padrão atualmente vigente, produzida no século XIX de forma mais ou menos artificial (cf. FARACO e ZILLES, 2017, p.100-116), a comunidade brasileira se vê relegada a uma condição de "orfandade normativa". A questão, portanto, conforme defendem com muita lucidez Faraco e Zilles (2017), não é se se deve ou não fixar um estândar para o PB, mas sim como fazê-lo.

nem a Academia Brasileira de Letras (ABL) são "academias da língua" no mesmo sentido que o são as academias espanhola, francesa e italiana. Assim, por exemplo, é só em 2001 que a ACL publica seu primeiro dicionário geral da língua - feito que a $\mathrm{ABL}$, até o presente momento, ainda não conseguiu realizar. Os mais importantes dicionários brasileiros segundo Welker (2004) - quais sejam, Dicionário Houaiss da língua portuguesa (Hou, 2001) (e sua edição reduzida, HouE, 2009), Novo Dicionário Aurélio da Língua Portuguesa (AuE, 2009), Michaelis Moderno Dicionário da Língua Portuguesa (Mi, 1999) e Dicionário de usos do Português do Brasil (DUPB, 2002) - são obras de autor, concebidas, nos três primeiros casos, por filólogos que, no entanto, e sem que isso lhes roube o mérito pelo trabalho realizado, tinham pouca ou nenhuma expertise lexicográfica

12 A primeira reforma ortográfica do português, por exemplo, como projeto unilateral de Portugal, foi levada a cabo somente nos primórdios do século XX, em 1911. Soma-se a isso o fato de que essa primeira reforma ficou a cargo da iniciativa privada, alijando-se, pois, a ACL do processo (cf. CASTRO, 2007).

13 As discussões concernentes ao pluricentrismo do português costumam centrar-se na oposição entre a norma da antiga metrópole e a(s) norma(s) emergida(s) no Brasil. O problema dos estândares africanos e asiáticos é raramente aludido. A exceção são os casos em que se debate a unifcação ortográfca e a possibilidade de constituição de uma "norma convergente" para o português (cf., por exemplo, OLIVEIRA, 2013) - proposta que, evidentemente, em razão de sua identifcação com a ideologia "unidade na diversidade", afasta-se da ideia original de pluricentrismo. Devese, no entanto, ressaltar que, muito embora, de fato, o estândar europeu ainda exerça muita infuência nos espaços lusófonos africanos e asiáticos, há variedades nacionais nessas regiões, mais especifcamente as de Angola (cf. BANZA, 2015; SANTOS, 2018), Moçambique (cf. MAPASSE, 2017) e Timor-Leste (cf. BATORÉO e CASADINHO, 2009; BATORÉU, 2016a), que se encontram em estágios mais ou menos avançados de desenvolvimento. Oliveira (2016), amparando-se especialmente na variável demográfca, projeta, já para meados do século XXI, uma mudança importante no âmbito da cultura linguística lusófona, uma vez que, com a emergência dos estândares angolano, moçambicano e timorense, deixaria de ser bicêntrica, e passaria a ser, de fato, pluricêntrica.

Vol. 25 - Ano $44-n^{\circ} 2-2020$ 
Em vista do exposto até aqui, o objetivo que se propõe é analisar como se leva a cabo a codificação normativa nos dicionários brasileiros de português mais difundidos nacionalmente $A u E$ e $H o u E^{14}$-, a fim de aferir (i) sua coerência do ponto de vista metalexicográfico e (ii) o êxito real obtido na consecução dos respectivos projetos. Para tanto, será necessário, previamente, discutir algumas questões fundamentais atinentes à codificação lexicográfica em geral, e à codificação do português em particular.

\section{A codificação normativa e os dicionários na cultura linguística}

O dicionário é um instrumento, até certo ponto, paradoxal. Por um lado, deveria sempre descrever os usos linguísticos a posteriori, em lugar de determiná-los - ou fixá-los a priori (cf. RABANALES, 1984, p.51). Por essa razão, parte-se, via de regra, de uma variedade - ou língua funcional, em termos coserianos, considerada exemplar -, que, por sua vez, serve como ponto de referência para o registro das formas pertencentes a outras variedades diassistematicamente diferenciadas. Ao dicionário cabe, pois, a codificação do estândar e, concomitantemente, a descrição da variação (cf. KILIAN, 2005). Por outro lado, no entanto, ao considerar determinados usos "neutros", enquanto são imputadas marcas diassistemáticas a outros, o dicionário adquire obrigatoriamente um caráter normativo, outorgado, em parte, pelos próprios usuários, que recorrem a essa ferramenta para satisfazer seu anseio de "correção". ${ }^{15}$ Trata-se do que Welker (2004, p.183-191) chama de "efeito normativo" - que pode produzir-se inclusive nos chamados "dicionários de usos", em princípio, eminentemente descritivos.

Fica evidente, portanto, que descrição e prescrição não se excluem mutuamente no âmbito (meta)lexicográfico, mas que, pelo contrário, devem ser interpretadas como dimensões complementares. Ao mesmo tempo em que se desfaz a aparente contradição anteriormentemencionada, esclarece-se, doponto de vista linguístico, que a normatividade é inerente ao dicionário (cf. ZANATTA e BUGUEÑO MIRANDA, 2007), e reforça- se, do ponto de vista (meta)lexicográfico, que os conceitos de descrição e prescrição desempenham

14 Os outros dois dicionários anteriormente mencionados não serão considerados na análise. $M i E$, em comparação com as demais obras, possui uma nomenclatura bem mais modesta. DUPB, por outro lado, é, de fato, apesar dos problemas que eventualmente podem ser-lhe apontados (cf. ZANATTA, 2010, p.108-180), o único dicionário brasileiro integral stricto sensu, cuja seleção macroestrutural foi baseada em um corpus do PB constituído exclusivamente para esse fim (o corpus do Laboratório de Lexicografia da Faculdade de Ciências e Letras de Araraquara, cf. 2.2). Não obstante, a microestrutura da obra é extremamente complexa, devido, sobretudo, à preponderância que se outorga à informação sintática, razão pela qual não obteve muito êxito entre o público leigo no Brasil.

15 Diferenciam-se, aqui, de acordo com Coseriu (1990, p.45 ss.), os conceitos de correção - defnido no âmbito da língua funcional - e exemplaridade - concernente ao plano da língua histórica. O autor adverte que é preciso evitar posições antagônicas - e frequentemente extremistas - que pretendem reduzir a exemplaridade à correção - postura, aliás, predominante nas discussões sobre o estândar no Brasil (cf. ZANATTA, 2009; FARIAS, 2011; 2019b) -, ou, pelo contrário, restringir o correto ao exemplar, justamente porque, entre outras razões, os referidos conceitos, por corresponderem a diferentes âmbitos, não são equiparáveis. A esse respeito, cf. também Polo (2012) e Martí Sánchez (2013). 
um papel fundamental na interação entre lexicografia e cultura linguística (cf. TARP e GOUWS, 2008, p.235 ss.).

Posto isso, há três dimensões da codificação normativa em dicionários gerais de língua que, segundo FARIAS (2011), devem ser levadas em consideração: (i) dimensão estritamente linguística, (ii) dimensão metodológica e (iii) dimensão (meta)lexicográfica. A seguir, tratar-se-á brevemente de cada uma dessas dimensões em relação às línguas pluricêntricas - e, mais especificamente, ao português.

\subsection{Dimensão linguística}

A identificação do estândar e subsequente delimitação dos elementos diassistematicamente diferenciados, como problemas ontológicos da linguagem, exigem que se encare, por um lado, a complexidade inerente ao fenômeno da variação linguística (cf. COSERIU, 1980; 1982; KOCH e OESTERREICHER, 2011; KABATEK, 1999) e, por outro lado, a questão da exemplaridade e sua "localização" no âmbito da língua histórica (cf. COSERIU, 1990; 2006; KREFELD, 2011a; 2018).

Especificamente em relação a este último aspecto, deve-se ressaltar a sua "tridimensionalidade". Assim, primeiramente, do ponto de vista sistêmico-linguístico, a língua/norma exemplar, nos termos coserianos, é compreendida, na linguística variacional, como magnitude ordenadora do espaço variacional, posto que é a partir dela que se identificam e hierarquizam as demais variedades (cf. KOCH e OESTERREICHER, 2011; OESTERREICHER, 2002). Diante, pois, da emergência de arquiteturas pluricêntricas, o(s) estândar(es) surgido(s) - que, agora, concorre(m) com o antigo estândar central - exigem que se descreva a nova ordenação do espaço variacional da língua histórica.

Além de sua dimensão sistêmico-linguística, a exemplaridade possui, ainda, outras duas, que, inclusive, precedem a primeira: a social, posto que se trata de uma demanda oriunda do "anseio normativo" dos falantes (cf. FARIAS, 2018b), ${ }^{16}$ e a política, devido a que sua fixação e implementação costumam ser consequência de projetos de planificação linguística (cf. LEBSANFT e TACKE, 2020). Nesse sentido, o estândar - materialização da exemplaridade sistêmico-linguística - é produto de intervenção política como resposta a uma demanda de caráter social. Aindissociabilidade dessas três dimensões - social, política e sistêmico-linguística - é o que torna a questão da estandardização tão polêmica. Isso fica

16 O anseio normativo (cf. ZANATTA, 2009, p.81 ss.), gerado no nível do saber idiomático (acerca dos três níveis do saber linguístico, cf. COSERIU, 2000), manifesta-se, sobretudo, nas esferas de comunicação formal - e/ou de distância comunicativa - e, portanto, na língua escrita, uma vez que há uma relação íntima - ainda que jamais exclusiva entre formalidade/distância comunicativa e escrita (cf. KOCH e OESTERREICHER, 2011, p.14 ss.; KABATEK, 1999). É através da consulta a obras de referência como vocabulários ortográficos, gramáticas e dicionários que os falantes buscam satisfazer seu anseio normativo. 
especialmente claro no debate em torno à normatização linguística no Brasil, conformeo exposto nas páginas introdutórias.

Posto o anterior, em se tratando de línguas que possuem projetos explícitos de planificação linguística, as instituições reguladoras dos usos linguísticos costumam ocuparse da estandardização por meio da publicação de obras de referência, como ocorre com o espanhol ou o francês. No caso de línguas que não contam com academias, como, por exemplo, o alemão ou o inglês, essa tarefa pode ficar a cargo de instituições públicas ou privadas - por exemplo, o Institut für Deutsche Sprache, no caso do alemão - ou, ainda, de grandes editoras - por exemplo, Duden e Langenscheidt, no caso do alemão, ou Oxford e Webster, no caso do inglês.

No que se refere à cultura linguística lusófona, como se sabe, não existe uma instituição análoga à RAE ou à Acadèmie Française (AF) - seja aquém ou além mar. Correia e Ferreira (2013), ao dissertarem sobre o problema normativo no âmbito da lusofonia, ressaltam, ainda, que tampouco há obras de referência que tenham se imposto por sua ampla difusão. Em princípio, a ausência de uma academia ou instituição equivalente não deveria ser um fator determinante para a consecução exitosa de um projeto de estandardização linguística, seja mono- ou pluricêntrica. Considere-se, por exemplo, os casos, respectivamente, do alemão e do inglês (cf. PÖLL, 2012). No âmbito lusófono, no entanto, faltam iniciativas mais assertivas em relação à estandardização linguística - sobretudo no caso das ex-colônias. Especificamente no Brasil, o argumento do poder coercitivo do estândar - conforme se discutiu na introdução do presente artigo -, contribui, em grande parte, para emperrar a atuação das instâncias públicas ou privadas - ou mesmo, no plano individual, dos profissionais (linguistas, sobretudo) - que poderiam encarregar-se da concepção e execução de projetos de planificação e codificação linguística. Nesse sentido, o state of the art relativo à normatização linguística hoje no Brasil, longe de ser resultado de mera inércia, parece ser mais propriamente produto de uma não atuação deliberada, corroborando-se, assim, a máxima de que "não fazer também é fazer". Isso, no entanto, é prejudicial, tanto do ponto de vista social, considerando a já aludida "orfandade normativa" dos brasileiros, como do ponto de vista sistêmico-linguístico, postoqueumadescriçãoadequadadavariedadenacional brasileira possibilitaria obter uma visão mais concreta acerca da reordenação do espaço variacional lusófono e, por conseguinte, fortaleceria o discurso político-ideológico em favor do pluricentrismo.

\subsection{Dimensão metodológica}

Adimensão metodológica-intimamente relacionada à linguística-abarca os problemas práticos concernentes ao reconhecimento empírico e à descrição da(s) língua(s)/norma(s) 
exemplar(es) e, consequentemente, da variação. Entre as ferramentas mais importantes para a consecução desse fim, encontram-se os atlas linguísticos. No âmbito lusófono, porém, projetos desse tipo são relativamente incipientes. A título de ilustração, mencionam-se aqui, relativamente ao PE, o Atlas Lingüístico de la Península Ibérica $(A L P I)^{17}$ - cujo objetivo é a descrição dos domínios linguísticos ibéricos - e, mais recentemente, o Atlas LinguísticoEtnográfico de Portugal e da Galiza $(A L E P G)^{18}$ - projeto ainda em curso, que investiga aspectos linguísticos e etnográficos da região fronteiriça em questão. Em relação ao Brasil, deve-se mencionar, inicialmente, a escassez de propostas teórico-metodológicas - posteriores à tentativa de Nascentes (1953) de delimitação dos "falares brasileiros" - que permitam a demarcação das zonas dialetais em território nacional. Entretanto, convém recordar que, na esteira de Nascentes, está em pleno desenvolvimento o projeto Atlas Linguístico do Brasil $(A l i B)^{19}$ - que hoje já conta com dois de seus volumes publicados.

Os corpora, por sua vez, são outra importante ferramenta. Entre os projetos mais ambiciosos de constituição de corpora de língua portuguesa, encontra-se $O$ Corpus do Português $(O C P)$, dirigido pelo Prof. Dr. M. Davies na Brigham Young University. Os bancos de dados do $O C P$ reúnem material linguístico oriundo de diversas variedades do português, de tal forma que o $O C P$ se caracteriza como um projeto "panlusitano". ${ }^{20}$ Não obstante, projetos desse tipo, cuja possibilidade de execução exitosa é posta em xeque ante as dificuldades que a coleta do material linguístico impõe em todos os níveis, embora devam ter seu mérito reconhecido, poderiam ceder lugar a outros relativamente mais modestos, por dizê-lo de alguma maneira, que objetivem a constituição de corpora nacionais. Nesse sentido, e no que concerne ao PB, Trask (2006, p.311-312) destaca que há três corpora sincrônicos contemporâneos importantes, entre os quais se destaca o corpus do Laboratório de Lexicografia da Faculdade de Ciências e Letras de Araraquara. ${ }^{21} \mathrm{O}$ banco de dados produzido - talvez o mais completo relativo ao $\mathrm{PB}$ - reúne amostras de língua escrita, com textos extraídos de obras literárias e técnicas, jornais e revistas, tendo servido de base para a elaboração de gramáticas (NEVES, 2000) e dicionários (DUPB e Dicionário UNESP do Português Contemporâneo [DUPC]). Deve-se ressaltar, contudo, que, quanto ao recorte

17 Para uma descrição dos objetivos, metodologia e consulta das cartas do ALPI disponibilizadas on-line, cf. http://alpi.csic.es/es; acesso em: 10.07.2020.

18 Para mais informações sobre a atual situação do $A L E P G$, cf. http://www.frontespo.org/pt; acesso em: 10.07.2020

19 Para mais informações sobre a atual situação do $A L i B$, cf. https://alib.ufba.br/; acesso em: 13.08.2020

20 Para mais informações sobre o OCP, cf. http://www.corpusdoportugues.org/; acesso em: 13.08.2020.

21 Os outros dois são, respectivamente, o corpus do projeto Norma Urbana Culta (NURC) e o do projeto Atlas Linguístico-Etnográfco da Região Sul (ALERS). Embora, evidentemente, ambos mereçam um voto de louvor pela importância que têm relativamente à descrição do $\mathrm{PB}$, convém salientar que os dados recolhidos nos dois casos restringem-se à modalidade oral e, especifcamente no que diz respeito ao $A L E R S$, a variedades marcadas diatopicamente (limita-se a dados linguísticos dos três estados que integram a Região Sul do país) e diastrático-diafasicamente (registra a fala de populações rurais de baixa escolaridade em contextos de interação informal).

Vol. $25-$ Ano $44-n^{\circ} 2-2020$ 
sincrônico proposto, o corpus apresenta algumas falhas que comprometem sua fiabilidade, incorporando, por exemplo, material linguístico anterior a 1950 - data estabelecida como ponto de partida para a recolha dos dados linguísticos (cf. FARIAS, 2011).

No que se refere, por sua vez, às obras de referência, Correia e Ferreira (2013, p.315-318) salientam que o projeto do vocabulário ortográfico comum, por exemplo, levado a cabo pelo Instituto Internacional da Língua Portuguesa (IILP), ao prever a produção e posterior fusão dos vocabulários nacionais de cada um dos países cujo português é língua oficial, poderia ter, para a Comunidade de Países de Língua Oficial Portuguesa (CPLP), impactos positivos no âmbito da codificação ortográfica. O projeto, no entanto, ainda está em curso, havendo sido disponibilizados apenas os vocabulários ortográficos do Brasil, Cabo Verde, Moçambique, Portugal e Timor-Leste. ${ }^{22}$

Em relação à codificação gramatical, as obras publicadas no Brasil e em Portugal tendem à descrição das respectivas variedades nacionais em cada caso (cf. BATORÉO, 2014; 2016b) - o que, deve-se dizer, é extremamente desejável, tendo em vista a comprovação empírica do pluricentrismo no âmbito lusófono. ${ }^{23}$ No entanto, deve-se salientar que, no Brasil, se, por um lado, as gramáticas consideradas tradicionais (cf. BECHARA, 2009; CUNHAe CINTRA, 2001) pecam ao privilegiar os usos dos "autores clássicos", aproximando-se mais da norma forjada no século XIX do que das variedades consideradas cultas efetivamente difundidas hoje entre a população, por outro lado, as gramáticas descritivas publicadas nas duas últimas décadas (cf. NEVES, 2000; PERINI, 2010; CASTILHO, 2010; BAGNO, 2011), não obstante representem, de fato, um avanço em relação às anteriores, tampouco contribuem de maneira efetiva para a fixação de um estândar brasileiro, pois não costumam conjugar a descrição dos dados linguísticos com uma apreciação dianormativa dos mesmos.

Por último, com relação à norma lexical, se, por um lado, os grandes projetos lexicográficos brasileiros - como $A u E$ ou $H o u E$ - restringem-se, em princípio, à circulação nacional, os portugueses - como o Dicionário da língua portuguesa contemporânea $(D L P C)$-, por outro lado, são potencialmente supranacionais, devido a que, com exceção do Brasil, os demais países pertencentes à CPLP - Angola, Cabo Verde, Guiné-Bissau, Moçambique, São Tomé e Princípe e Timor-Leste -, que são também aqueles onde o estândar europeu continua sendo prestigiado (cf. OLIVEIRA, 2016), ainda não contam

22 Informações disponíveis no site do IILP (cf.: http://voc.iilp.cplp.org/; acesso em: 08.08.2020).

23 Batoréo (2014; 2016b), no entanto, avalia esse fato como algo negativo. A autora considera que as gramáticas do português deveriam, a exemplo da Nueva Gramática de la Lengua Española (NGLE), objetivar uma codificação "pluricêntrica", com base no argumento de que, ao refletir, idealmente, a pluralidade de normas lusófonas, facilitariam o ensino do português como língua estrangeira. Um empreendimento desse tipo, porém, não só é de difícil execução, conforme demonstra a análise da própria NGLE (cf. GREUSSLICH, 2015), como também suscita dúvidas em relação às intenções que encobre, uma vez que encarna uma "ideologia pan-lusitana" (cf. CASTRO, 2007; 2009; SILVA, 2017; 2018a), mais afm à convergência do que à divergência - esta última, sim, característica essencial do pluricentrismo.

Vol. 25 - Ano $44-n^{\circ} 2-2020$ 
com recursos lexicográficos próprios (cf. CORREIA e FERREIRA, 2013, p.317). ${ }^{24}$ Não obstante, enquanto o $D L P C$ parece ter sido concebido como um dicionário supranacional monocêntrico (cf. FARIAS, 2020c), em consonância com o discurso normativo vigente em Portugal (cf. nota 23), os dicionários brasileiros, aparentemente, como se verá a seguir, não refletem, na sua concepção, uma proposta de "codificação nacional”.

\subsection{Dimensão (meta)lexicográfica}

A codificação lexicográfica, segundo a proposta de BUGUEÑO MIRANDA e FARIAS (2006; 2009), deve estar orientada por três axiomas básicos: (i) a definição taxonômica do dicionário, (ii) o perfil do usuário e (iii) as funções que a obra deve cumprir. Comentarse-á, aqui, apenas o primeiro dos axiomas. ${ }^{25}$

A definição taxonômica do dicionário consiste na sua classificação de acordo com um sistema de critérios pré-determinados, que possibilita, por conseguinte, atribuir traços específicos a um dado genótipo lexicográfico (cf. BUGUEÑO MIRANDA, 2014). No que concerne ao genótipo "dicionário geral”, este, segundo a classificação de Welker (2004), pode ser exaustivo ou seletivo. Entre os traços atribuíveis a estas categorias, conforme Bugueño Miranda (2014) estão: (i) ser monolíngues; (ii) destinar-se a falantes nativos; (iii) privilegiar o discurso livre; (iv) possuir ênfase no significado; (v) ser semasiológico; e (vi) ser aberto diassistematicamente. No caso de dicionários gerais exaustivos - inexistentes no âmbito lusófono (cf. WELKER, 2004) -, o critério da abertura diassistemática nãoestará sujeito a restrições, uma vez que este genótipo deve registrar, idealmente, todo o léxico da língua em questão. Por outro lado, no caso dos dicionários gerais seletivos - a exemplo de $A u E$ e $H o u E$-, a abertura diassistemática do dicionário - e, por conseguinte, os parâmetros de seleção macroestrutural - estarão determinados pelo público ao que se destina a obra e pela funçãoque esta deve cumprir.Levandoem consideraçãoessas duas variáveis, emFARIAS (2020c), aventou-se a possibilidade de três tipos de codificação normativa, com consequências distintas no que concerne à abertura dissistemática das respectivas obras: (1) codificação supranacional monocêntrica: o dicionário estaria destinado a toda a comunidade lusófona e cumpriria sua função de orientação normativa mediante a fixação de um estândar único baseado em critérios ou estatísticos ou prescritivos (a esse respeito, cf. ETTINGER, 1982) -, com a consequente redução das demais possibilidades diassistemáticas a mera variação regional; ${ }^{26}$ (2) codificação supranacional pluricêntrica: o dicionário estaria destinado a

24 Para um panorama da produção lexicográfca brasileira, cf. Welker (2006b); para uma revisão crítica do percurso da lexicografa no Brasil, cf. Bugueño Miranda (2011); para um panorama geral do desenvolvimento da lexicografa em Portugal, cf. Verdelho (1994).

25 Sobre a questão do usuário e seu (quase) absoluto desconhecimento, cf. Wiegand (1977) e Welker (2006a); acerca da função dos dicionários, em especial no âmbito escolar, cf. Tarp e Gouws (2010; 2012).

26 Esse parece ser, em princípio, o tipo de codifcação proposta em DCLP (cf. FARIAS, 2020c).

Vol. $25-$ Ano $44-n^{\circ} 2-2020$ 
toda a comunidade lusófona e cumpriria sua função de orientação normativa mediante a construção do estândar a partir de uma realidade plurinormativa, fator que viabilizaria, ao menos idealmente, a representação dos diversos espaços variacionais que configuram a arquitetura da língua histórica em questão; ${ }^{27}$ (3) codificação nacional: o dicionário estaria destinado a uma comunidade/um país específica(o) e cumpriria sua função de orientação normativa mediante a fixação de um estândar nacional e a descrição do espaço variacional correspondente, com exclusão total de outras variedades. ${ }^{28}$

\section{A codificação normativa nos dicionários brasileiros: um esboço de conclusão}

Levando em conta que se trata de compatibilizar a descrição sistêmico-linguística do português com a percepção mais ou menos generalizada do seu pluricentrismo do ponto de vista político-ideológico, a produção de dicionários integrais de codificação nacional para cada um dos países membros da CPLP parece ser a opção mais viável. Nesse sentido, se uma codificação supranacional monocêntrica poderia ser descartada a priori - ainda que seja afim a ideologias linguísticas específicas -, uma codificação supranacional pluricêntrica que, em teoria, poderia ser considerada uma alternativa viável, na prática, como demonstra a análise das obras académicas hispânicas (cf. GREUSSLICH, 2015; FARIAS, 2018a; 2018b), não costuma apresentar resultados completamente satisfatórios. Não obstante, e embora haja se consolidado, no Brasil, uma lexicografia supostamente integral, uma vez que as principais obras estão, em princípio, destinadas à circulação nacional, a codificação normativa proposta em dicionários como $A u E$ e $H o u E$ não corresponde exatamente ao que se esperaria de uma obra deste tipo. No âmbito macroestrutural, por exemplo, não é incomum o registro de unidades léxicas e acepções próprias e/ou exclusivas do PE:

açorda [...] Substantivo feminino. Lus. 1. Cul. Sopa de migas de pão, temperada com azeite, alho e coentro, ou preparada com ovos, manteiga e açúcar: [...] 2. Cul. Miolo de pão embebido em água fervente ou num caldo, e ger. condimentado com alho e azeite. 3. Fig. Pessoa fraca, medrosa, moleirona. (AuE, s.v.)

açorda [...] substantivo feminino 1 Rubrica: culinária. Regionalismo: Portugal. caldo transparente, temperado com coentro e alho, que se despeja sobre fatias de pão e se come ger. com um ovo poché, entre outros acompanhamentos; sorda 2 Rubrica: culinária. Regionalismo: Portugal. espécie de papa de miolo de pão ensopado em água fervente ou em um caldo, temperada com azeite e alho, e que ger. acompanha peixes e frutos do mar; sorda 3 Derivação:

27 Como exemplo deste tipo de codifcação, menciona-se a pretendida na última edição do Diccionario de la lengua española (DLE), que, no entanto, não parece ter sido de todo bem sucedida (cf. FARIAS, 2018a; 2018b).

28 Exemplos de dicionários integrais são os já mencionados DEUM, DEM e DIEA (cf. nota 10).

Vol. 25 - Ano $44-n^{\circ} 2-2020$ 
sentido figurado. Regionalismo: Brasil. Uso: informal, pejorativo. m.q. PAPA-AÇORDA (HouE, S.V. $)^{29}$

Ao registro de lusismos nos dicionários brasileiros, soma-se o de luso-africanismos e luso-asiaticismos. Fica, no entanto, evidente a falta de sistematicidade que caracteriza, no nível macroestrutural, a inclusão dessas unidades léxicas em ambos os dicionários, ${ }^{30}$ bem como, no nível microestrutural, a atribuição das marcas diatópicas correspondentes (cf., por exemplo, AuE e HouE, s.v. pantim ${ }^{I}$ ):

calulu [...] Substantivo masculino. 1.Angol. Santom. Cul. Prato de origem santomense, preparado com peixe (ou, eventualmente, com galinha), óleo de palma, rama de batata-doce, cebola batida, quiabos e outros legumes, acompanhado de funje (1), em Angola, ou de angu (2), em São Tomé e Príncipe: [...] (AuE, s.v.)

pantim $^{l}[\ldots]$ Substantivo masculino. 1. Luso-asiat. Lamparina de barro ou de bronze. $(A u E$, s.v. $)$

${ }^{1}$ pantim [...] substantivo masculino Regionalismo: Índia. lamparina de barro ou de bronze (HouE, s.v.)

A análise dos verbetes apresentados poderia levar a supor que se trata de tentativas de codificação pluricêntrica. Essa hipótese pode ser corroborada, ainda, pela indicação da marca brasileirismo - acompanhada, muitas vezes, de marcas (redundantes) de regionalismo:

aipim [...] Substantivo masculino. 1. Bras. Bot. V.mandioca (1 e 2) (AuE, s.v.)

macaxeira [...] Substantivo feminino. 1. Bras. N. N.E. Bot. V. mandioca (1 e2) [...] (AuE, s.v.)

mandioca $[\ldots]$ Substantivo feminino. Bras. 1. Bot. Planta leitosa, da família das euforbiáceas (Manihotutilissima), cujos grossos tubérculos radiculares, ricos em amido, são de largo emprego na alimentação, e da qual há espécies venenosas, que servem para fazer farinha de mesa. 2. Bot. O tubérculo dessa planta. [...] Substantivo masculino. 3. Bras. BA Certo partido político conservador, na Monarquia. 4. Bras. BA Adepto desse partido. [...] (AuE, s.v.)

Em síntese, por um lado, o registro abundante de lusismos e a presença da marca brasileirismo poderia indicar que, em $A u E$ e HouE, encontram-se duas propostas de codificação supranacional pluricêntrica. Este tipo de codificação, no entanto, ainda que não seja um equívoco per se, poderia ser alvo de crítica, se se considera a natureza do genótipo em questão e, principalmente, o público a que se dirigem os dois dicionários analisados e a

29 Não serão analisadas, aqui, as defnições apresentadas. Entretanto, não se pode deixar de mencionar o emprego, nas paráfrases defnidoras, de unidades léxicas próprias do PE (por exemplo, migas, em $A u E$, s.v. açorda) ou pouco usuais no PB (por exemplo, moleirão, em $A u E$, s.v. açorda), bem como a apresentação, no segmento destinado às informações paradigmáticas, de sinônimos que parecem corresponder a usos exclusivos do PE (por exemplo, sorda, em HouE, s.v. açorda).

30 A marca Luso-asiat., por exemplo, aparece só vinte e uma vezes em um total de 435.000 acepções registradas em $A u E$.

Vol. 25 - Ano $44-n^{\circ} 2-2020$ 
função que devem cumprir. Por outro lado, a falta de sistematicidade em relação ao registro e imputação de uso das unidades léxicas provenientes das variedades africanas e asiáticas, assim como seu reduzido número em comparação com as unidades léxicas próprias e/ou exclusivas do PE, enfraquece a hipótese de uma codificação pluricêntrica - ou, ao menos, indica uma falha na sua consecução, considerando que a presença de luso-africanismos e luso-asiaticismos, em ambos os dicionários, parece ser produto de mera curiosidade filológica, e não um real compromisso com a apresentação de um retrato fidedigno do português e sua condição pluricêntrica.

Por fim, e à guisa de conclusão, deve-se ressaltar que não só a desatenção às dimensões social e sistêmico-linguística da estandardização - que, conforme o exposto nas páginas precedentes, vem entorpecendo a execução de um projeto de estandardização adequada do $\mathrm{PB}$-, ou o fato de que os dicionários brasileiros não estão concebidos com base em sólida teoria (meta)lexicográfica (cf. BUGUEÑO MIRANDA, 2011), são responsáveis pelos problemas identificados na codificação normativa levada a cabo em $A u E$ e HouE. Conforme o exposto em 2.2, a escassez de instrumentos metodológicos adequados para a descrição da variação no português - e, mais especificamente, no PB - em todos os níveis talvez seja, hoje, a principal responsável pela inviabilidade de uma codificação pluricêntrica exitosa no âmbito lusófono-e, principalmente, de projetos de codificação nacional no Brasil e nas regiões lusófonas da África e da Ásia. Uma estandardização adequada, ao menos no âmbito do PB, é, hoje, imprescindível para uma comprovação empírica do pluricentrismo do português, e a elaboração de dicionários integrais stricto sensu no Brasil poderia vir a ser um passo importante nessa direção.

\section{Referências bibliográficas}

ANTUNES, Luísa Marinho. O português como língua de cultura: tradição e inovação. In: BASTOS, Neusa Barbosa (org.). Língua portuguesa e lusofonia. São Paulo: EDUC, 2014, p.67-76. AuE. FERREIRA, Aurélio Buarque de Holanda (dir.). Novo Dicionário Aurélio da Língua Portuguesa. Curitiba: Positivo, 2009. (1 CD-ROM)

BAGNO, Marcos. Preconceito linguístico. O que é, como se faz. $4^{\mathrm{a} e d . ~ S a ̃ o ~ P a u l o: ~}$ Edições Loyola, 2001.

. Gramática pedagógica do português brasileiro. São Paulo: Parábola, 2011.

Língua, história e sociedade. Breve retrospecto da norma padrão brasileira. In:

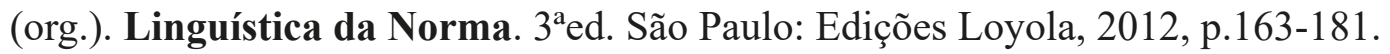

BANZA, Ana Paula. O português em Angola: Uma questão de política linguística. In: MADEIRA, Ana; LOBO, Maria; FIÉIS, Alexandra (orgs.). O Universal e o Particular: uma Vida a Comparar. Lisboa: Edições Colibri, 2015, p.29-38. 
BATORÉO, Hanna. Que gramática(s) temos para estudar o Português língua pluricéntrica? Diadorim, n.16, p.1-15, 2014.

The contact induced partial restructuring of the non-dominant variety of Portuguese in East Timor. In: MUHR, Rudolf (ed.). Pluricentric Languages and Non-Dominant Varieties Worldwide. Frankfurt am Main: Peter Lang, 2016, p.145-159.

Gramáticas de costas voltadas. Que futuro para o ensino do Português língua pluricêntrica a falantes não nativos? In: HLIBOWICKA-WEGLARZ, Barbara; WISNIEWSKA, Justyna; JABLONKA, Edyta (eds.). Língua Portuguesa: Unidade e Diversidade. Lublin: Editora da Universidade Marie Curie-Sklodowska, 2016b, p.93-108. BATORÉO, Hanna; CASADINHO, Margarida. O português - uma língua pluricêntrica: O caso de Timor-Leste. Revista Portuguesa de Humanidades, Estudos Linguísticos, v.13(1), p.63-79, 2009.

BAXTER, Alan. Portuguese as a Pluricentric Language. In: CLYNE, Michael (ed.). Pluricentric languages: Differing Norms in Different Nations. Berlin; New York: Mouton de Gruyter, 1992, p.11-44.

BECHARA, Evanildo. Moderna gramática portuguesa. $37^{\mathrm{a}} \mathrm{ed}$. Rio de Janeiro: Nova Fronteira; Lucerna, 2009.

BERGENHOLTZ, Henning. Sprachkultur, Lexikographie und Wörterbuchbenutzung. Bemerkungen zu: Jürgen Scharnhorst (Hrsg.): Sprachkultur und Lexikographie. Von der Forschung zur Nutzung von Wörterbüchern. Hermes, v.37, p.131-137, 2006.

BIERBACH, Mechtild. Spanische-eine plurizentrische Sprache? Zum Problem von norma culta und Varietät in der hispanophonen Welt. Vox Romanica, v.59, p.143-170, 2000.

BUGUEÑO MIRANDA, Félix. Panorama da lexicografia brasileira de orientação semasiológica. In: BATTISTI, Elisa; COLLISCHONN, Gisela (orgs.). Língua e Linguagem: Perspectivas de investigação. Pelotas: EDUCAT, 2011, p.173-206.

Da classificação de obras lexicográficas e seus problemas: proposta de uma taxonomia. Alfa, n.58(1), 215-231, 2014.

BUGUEÑO MIRANDA, Félix; FARIAS, Virginia Sita. Informações discretas e discriminantes no artigo léxico. Cadernos de Tradução, v.2(18), p.115-135, 2006.

. Panorama crítico dos dicionários escolares brasileiros. Lusorama, v.77/78, p.29-78, 2009.

CASTILHO, Ataliba de. O português do Brasil. In: ILARI, Rodolfo (ed.). Lingüística

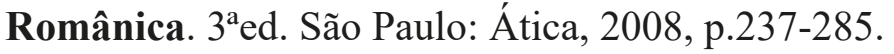

Nova gramática do português brasileiro. São Paulo: Contexto,2010.

CASTRO, Ivo. Forças de união e separação no espaço da língua portuguesa (conferência). Barcelona: Institut d'Estudis Catalans, 2007, p.1-14. Disponível em: http://www.clul. ulisboa.pt/files/ivo_castro/2007_Unio_e_Separao.pdf; consulta em: 18.08.2020.

Vol. $25-$ Ano $44-n^{\circ} 2-2020$ 
A internacionalização da língua portuguesa (comunicação). Lisboa: Associação Sindical dos Diplomatas Portugueses, 2009, p.1-6. Disponível em: http://www.clul.ulisboa. pt/files/ivo_castro/2009_Internacionalizao_do_Portugus.pdf; consulta em: 18.08.2020.

CLYNE, Michael. Pluricentricity: National Variety. In: AMMON, Ulrich (ed.). Status and Function of Languages and Language Varieties. Berlin; New York: Mouton de Gruyter, 1989, p.357-371.

Pluricentric languages -Introduction. In:__(ed.).Pluricentriclanguages: Differing Norms in Different Nations. Berlin; New York: Mouton de Gruyter, 1992a, p.1-9.

Epilogue. In:_(ed.).Pluricentriclanguages:DifferingNormsinDifferent Nations. Berlin; New York: Mouton de Gruyter, 1992b, p.455-466.

German as a pluricentric language. In:

(ed.).Pluricentriclanguages: Differing

Norms in Different Nations. Berlin; New York: Mouton de Gruyter, 1992c, p.117-148.

(ed.). Pluricentric languages: Differing Norms in Different Nations. Berlin; New York: De Gruyter, 1992d.

CLYNE, Michael; SHARIFIAN, Farzad. English as an international language: Challenges and possibilities. Australian Review of Applied Linguistics, v.31,n.3, p.28.1-28-16, 2008.

CORREIA, Margarita; FERREIRA, José. Dicionários e vocabulários ortográficos na constituição da norma. In: MOITA LOPES, Luiz Paulo (org.). O português no século XXI: cenário geopolítico e sociolinguístico. São Paulo: Parábola, 2013, p.297-318.

COSERIU, Eugenio. Sistema, norma y habla. In: Teoría del lenguaje y lingüística general. Cinco estudios. $2^{\mathrm{a}}$ ed. Madrid: Gredos, 1967, p.11-113.

Historische Sprache und Dialekte. In: GÖSCHEL, Joachim; IVIC, Pavle; KEHR, Kurt (orgs.). Dialekt und Dialektologie. Ergebnisse des Internationalen Symposions „Zur Theorie des Dialekts“(Marburg/Lahn, 5.-10. September 1977). Wiesbaden, 1980, p.106-122.

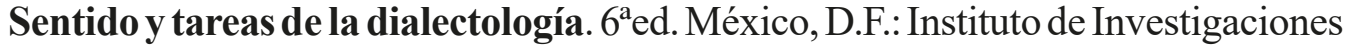
Filológicas; Centro de Lingüística Hispánica, 1982.

El español de América y la unidad del idioma. In: I Simposio de Filología Iberoamericana (Sevilla, 26 al 30 de marzo de 1990). Sevilla: Universidad de Sevilla, 1990, p.43-75.

. La estructura del saber lingüístico (ordenado y dispuesto para la imprenta por José Polo). Analecta Malacitana, v.23(2), p.437-452, 2000.

Lições de lingüística geral. Tradução de Evanildo Bechara. Rio de Janeiro: Ao Livro Técnico, 2004.

Vol. $25-$ Ano $44-n^{\circ} 2-2020$ 
Lenguaje y política. In: LOUREDA LAMAS, Óscar (ed.). Lenguaje y discurso. Barañáin: Ediciones Universidad de Navarra, 2006, p.35-56.

CUNHA, Celso; CINTRA, Lindley. Nova Gramática do Português Contemporâneo. $3^{\mathrm{a}}$ ed. Rio de Janeiro: Nova Fronteira, 2001.

DEM. LARA, Luis Fernando (dir.). Diccionario del español de México. México, D.F.: El Colegio de México, 2010.

DEUM. LARA, Luis Fernando (dir.). Diccionario del español usual en México. México, D.F.: El Colegio de México, 1996.

DIEA. PLAGER, Federico (dir.). Diccionario integral del español de la Argentina. Buenos Aires: Voz Activa, 2008.

DLE. RAE; ASALE. Diccionario de la lengua española. 23a ed. Madrid: Espasa.

DLPC. CASTEleiro, João Malaca (Dir.). Dicionário da Língua Portuguesa Contemporânea. Lisboa: Editorial Verbo, 2001.

$D U P B$. BORBA, Francisco da Silva. Dicionário de usos do Português do Brasil. São Paulo: Ática, 2002.

DUPC. BORBA, Francisco da Silva. Dicionário UNESP do Português Contemporâneo. São Paulo: UNESP, 2004.

DUARTE, Maria Eugênia; GOMES, Christina Abreu; PAIVA, Maria da Conceição. Codification and Standardisation in Brazilian Portuguese. In: MUHR, Rudolf (ed.). Pluricentric Languages and Non-Dominant Varieties Worldwide. Frankfurt am Main: Peter Lang, 2016, p.51-65.

ETTINGER, Stefan. La variación lingüística en lexicografía. In: HAENSCH, Günther et al. (eds.). La Lexicografía: de la lingüística teórica a la lexicografía práctica. Madrid: Gredos, 1982, p.359-394.

FARACO, Carlos Alberto. Lusofonia: utopia ou quimera? Língua, história e política. In: LOBO, Tânia et al. (orgs.). Rosae: linguística histórica, história das línguas e outras histórias. Salvador: EDUFBA, 2012, p.31-50.

História do português. São Paulo: Parábola, 2019.

FARACO, CarlosAlberto; ZILLES,Ana Maria. Norma linguística. São Paulo: Contexto, 2017. FARIAS, Virginia Sita. A questão da variação diatópica, diafásica e diastrática no português brasileiro e sua representação nos dicionários semasiológicos. Lusorama, v.87/88, p.100-155, 2011. 
La política lingüística panhispánica y su reflejo en las obras académicas. Consideraciones acerca del tratamiento de la variación diatópica y diastrático-diafásica en el DRAE. In: FRANKE, Anna-Susan; ÁLVAREZ VIVES, Vicente (orgs.). Romaniae Pontes. Beiträge zur Sprache in der Gallo- und Iberoromania. Berlin: Peter Lang, 2018a, p.161-174.

. Pluricentrismo, panhispanismo y lexicografía. Análisis de la codificación normativa en los corpora y diccionarios académicos. In: DÍAZ, Marta et al. (eds.). Actas do XIII Congreso Internacional de Lingüística Xeral. Vigo: Universidade de Vigo, 2018b, p.350-357.

Pluricentrismo e políticas acadêmicas: State of the art do debate no âmbito da cultura linguística hispânica. In: MESQUITA NETO, Jesus Rodrigues; FARIAS, Maria Solange de (eds.). Mosaico Hispânico: Novas perspectivas nas pesquisas em língua espanhola. Alagoinhas: Bordô-Grená, 2019a, p.163-180.

. O problema da norma padrão no Brasil. Uma reflexão sobre pluricentrismo, constituição de variedades nacionais e codificação linguística. In: GRAZIOLI, Fabiano Tadeu (ed.). A senda nos estudos da língua portuguesa. Ponta Grossa: Atena, 2019b, p.25-37.

Pluricentrismo, políticas académicas y los discursos sobre la lengua en la cultura lingüística hispánica. Voces, 2020a. [em avaliação editorial]

Ejemplaridad y (r)estandarización en contextos pluricéntricos. Lexis, 2020b. [em avaliação editorial]

El portugués y su pluricentrismo. El problema de la codificación normativa en diccionarios generales brasileños y portugueses. RILI, 2020c. [em avalação editorial] FIORIN, José Luis. As relações de poder entre as línguas e a dimensão política de seu uso. In: BASTOS, Neusa Barbosa (org.). Língua portuguesa e lusofonia. São Paulo: EDUC, 2014, p.55-66.

GREUSSLICH, Sebastian. El pluricentrismo de la cultura lingüística panhispánica: política lingüística, los estándares regionales y la cuestión de su codificación. Lexis, v.39(1), p.57- 99, 2015. GREUSSLICH, Sebastian; LEBSANFT, Franz. Introducción: Pluricentrismo, estándares regionales, normas implícitas y medios de comunicación masiva. In: (eds.).Elespañol, lengua pluricéntrica. Discurso, gramática, léxico y medios de comunicación masiva. Göttingen: V\&R unipress, 2020, p.11-38.

HAUGEN, Einar. The implementation of corpus planning: Theory and practice. COBARRUBIAS, Juan; FISHMAN, Joshua (eds.). Progress in language planning: International perspectives. Berlin: Mouton, 1983, p.269-289.

HEGER, Klaus. "Sprache" und "Dialekt" als linguistisches und soziolinguistisches Problem. Folia Linguistica, v.3, p.46-67, 1969. 
Zur Plurizentrischen Sprachkultur. Zeitschrift für germanistische Linguistik, n.17, p.226-228, 1989.

Rezension zu 'Michael Clyne (ed.): Pluricentric languages: Differing Norms in DifferentNations'.ZeitschriftfürDialektologie und Linguistik,n.60(2), p.211-213, 1993. Hou. HOUAISS, Antonio (ed.). Dicionário Houaiss da língua portuguesa. Rio de Janeiro: Objetiva, 2001.

HouE. INSTITUTO ANTONIO HOUAISS. Dicionário da língua portuguesa Houaiss Eletrônico. Rio de Janeiro: Objetiva, 2009. (1 CD-ROM)

KABATEK, Johannes. Sobre el nacimiento del castellano desde el espíritu de la oralidad (apuntes acerca de los textos jurídicos castellanos de los siglos XII y XIII). In: COMPANY, Concepción; GONZÁLEZ, Aurelio; VON DER WALDE MOHENO, Lillian (eds.). Discursos y representaciones en la Edad Media. México, D.F.: Universidad Nacional Autónoma de México; El Colegio de México, 1999, p.169-187.

Linguistic Norm in the Linguistic Theory of Eugenio Coseriu. In: LEBSANFT, Franz; TACKE, Felix (eds.). Manual of Standardization in the Romance Languages. Berlin; Boston: De Gruyter, 2020, p.127-144.

KAILUWEIT, Rolf. Los maestros de idiomas - Plurizentrische Sprachräume als kommunikatives Konstrukt. In: FELBECK, Christine; KLUMP, Andre; KRAMER, Johannes (orgs.). America Romana: Neue Perspektiven transarealer Vernetzungen. Frankfurt am Main: Peter Lang, 2015, p.97-119.

KILIAN, Jörg. Gute Wörter kommen ins Wörterbuch - böse überallhin. Konzepte und Defizite einer kritischen Semantik in der deutschen Lexikographie. Aptum. Zeitschrift für Sprachkritik und Sprachkultur, n.2, p.112-134, 2005.

KLOSS, Heinz.Abstand Languages and Ausbau Languages. Anthropological Linguistics, v.9(7), p.29-41, 1967.

Die Entwicklung neuergermanischer Kultursprachen seit 1800. $2^{\mathrm{a}}$ ed. Düsseldorf: Schwann, 1978.

KOCH, Peter. I generi del/nel parlato. In: AMENTA, Luisa; PATERNOSTRO, Giuseppe (eds.). I parlanti e le loro storie. Competenze linguistiche, strategie comunicative, livelli di analisi. Palermo: Centro Studi Filologici e Linguistici Siciliani, 2009, p.21-38.

KOCH, Peter; OESTERREICHER, Wolf. Gesprochene Sprache in der Romania: Französisch, Italienisch, Spanisch. 2 ${ }^{\mathrm{a} e d . ~ B e r l i n ; ~ N e w ~ Y o r k: ~ M o u t o n ~ d e ~ G r u y t e r, ~} 2011$.

KREFELD, Thomas. Sag mir, wo der Standard ist, wo ist er (in der Varietätenlinguistik) geblieben? In: DESSİ SCHMID, Sarah et al. (eds.). Rahmen des Sprechens. Beiträge

Vol. 25 - Ano $44-n^{\circ} 2-2020$ 
zur Valenztheorie, Varietätenlinguistik, Kreolistik, Kognitiver und Historischer Semantik. Tübingen: Narr, 2011a, p.101-110.

«Primäre», «sekundäre», «tertiäre» Dialekte - und die Geschichte des intalianischen Sprachraums. In: OVERBECK, Anja et al. (eds.). Lexikon, Varietät, Philologie. Romanistische Studien. Günter Holtus zum 65. Geburtstag. Berlin; Boston: De Gruyter, 2011, p.137-147.

. Varietà ibride? - Che cosa ne pensa la linguistica variazionale, Versione 4 (18.07.2018). Korpus im Text, SerieA. Disponível em: http://www.kit.gwi.uni-muenchen. $\mathrm{de} / ? \mathrm{p}=19051 \& \mathrm{v}=4$; consulta em 30.01.2019.

LANDAU, Sidney. Dictionaries. The art and craft of lexicography. $2^{\mathrm{a}} \mathrm{ed}$. Cambridge: CUP, 2001.

LARA, Luis Fernando. Teoría del diccionario monolingüe. México, D.F.: El Colegio de México, 1997.

. El papel de la lexicografía en la unidad y la diversidad de las lenguas. In: ADELSTEIN, Andreína; HLAVACKA, Laura (eds.). Lexicografía, lexicografía especializada y terminología. Mendoza:Editorial FFyL-UNCuyo y SAL,2015,p.21-35. LEBSANFT, Franz. Spanische Sprachkultur. Studien zur Bewertung und Pflege des öffentlichen Sprachgebrauchs im heutigen Spanien. Tübingen: Max Niemeyer, 1997.

Spanisch. In: JANICH, Nina; GREULE, Albrecht (orgs.). Sprachkulturen in Europa. Ein internationales Handbuch. Tübingen: Narr, 2002, p.295-301.

LEBSANFT, Franz; MIHATSCH, Wiltrud; POLZIN-HAUMANN, Claudia. Variación diatópica, normas pluricéntricas y el ideal de una norma panhispánica. In:_(eds.). El español, ¿desde las variedades a le lengua pluricéntrica? Madrid; Frankfurt am Main: Iberoamericana; Vervuert, 2012, p.7-18.

LEBSANFT, Franz; TACKE, Felix. Romance Standardology: Roots and Traditions. In: (eds.). Manual of Standardization in the Romance Languages. Berlin; Boston: De Gruyter, 2020, p.3-59.

LÓPEZ SERENA, Araceli. La heterogeneidad interna del español meridional o atlántico: variación disistemática vs. pluricentrismo. Lexis, v.37(1), p.95-161, 2013.

LUCCHESI, Dante. Norma linguística e realidade social. In: BAGNO, Marcos (org.). Linguística da Norma. $3^{\mathrm{a}}$ ed. São Paulo: Edições Loyola, 2012, p.57-83.

LÜDI, Georges. French as a pluricentric language. In: CLYNE, Michael (ed.). Pluricentric languages: Differing Norms in Different Nations. Berlin; New York: Mouton de Gruyter, 1992, p.149-178.

Prácticas pluricéntricas en la francofonía. In: MUHR, Rudolf et al. (eds.). Exploring Linguistic Standards in Non-Dominants Varieties of Pluricentric Languages. Wien: Peter Lang, 2013, p.67-78. 
LÜDTKE, Jens. La variación en el Atlas Lingüístico de México. In: MORGENTHALER GARCÍA, Laura; SCHRADER-KNIFFKI, Martina (eds.). La Romania en interacción: entre historia, contacto y política. Ensayos en homenaje a Klaus Zimmermann. Madrid; Frankfurt am Main: Iberoamericana; Vervuert, 2007, p.51-72.

MAPASSE, Ermelinda. Usos e avaliação social do português em Moçambique. Calidoscópio, v.15, n.2, p.240-253, 2017.

MARTÍ SÁNCHEZ, Manuel. Con motivo de José Polo, Entorno del universo normativo de Eugenio Coseriu. Cuaderno de Bitácora, 2012. RSEL, n.43(1), p.201-216, 2013.

MiE. MICHAELIS. Moderno Dicionário da Língua Portuguesa. São Paulo: Melhoramentos, 1999.

MUHR, Rudolf. Linguistic dominance and non-dominance in pluricentric languages: A typology. In:_(ed.). Non-dominant Varieties of pluricentric Languages. Getting the Picture. In Memory of Michael Clyne. Wien: Peter Lang, 2012, p.23-48.

NASCENTES, Antenor. O linguajar carioca. 2ª ed. Rio de Janeiro: Organização Simões, 1953. NEVES, Maria Helena de Moura. Gramática de usos do português. São Paulo: UNESP, 2000. NGLE. RAE; ASALE. Nueva gramática de la lengua española. Madrid: Espasa-Calpe, 2009/2010/2011, 3 vols.

NPLP. RAE; ASALE. Nueva Política Lingüística Panhispánica. Madrid, 2004.

OESTERREICHER, Wolf. Plurizentrische Sprachkultur - der Varietätenraum des Spanischen. Romanistisches Jahrbuch, n.51, p.287-318, 2000.

El español, lengua pluricéntrica: perspectivas y límites de una autoafirmación lingüística nacional en Hispanoamérica. El caso mexicano. Lexis, n.26(2), p.275-304, 2002. OLIVEIRA, Gilvan. Um Atlântico ampliado: o português nas políticas linguísticas do século XXI. In: MOITALOPES, Luiz Paulo (org.). O português no século XXI: cenário geopolítico e sociolinguístico. São Paulo: Parábola, 2013, p.53-73.

. The system of national standards and the demolinguistic evolution of Portuguese. In: MUHR, Rudolf(ed.). Pluricentric Languages and Non-Dominant Varieties Worldwide. Frankfurt am Main: Peter Lang, 2016, p.35-48.

PERINI, Mário. Gramática do português brasileiro. São Paulo: Parábola, 2010.

PÖLL, Bernhard. Portugiesische Kollokationen im Wörterbuch: Ein Beitrag zur Lexikographie und Metalexikographie. Bonn: Romanistischer Verlag, 1996.

Essai de standardologie comparée: quelques éléments pour una comparaison de l'espagnol et du portugais européens et américains. Revue belge de philologie et d'histoire, n.79(3), p.907-930, 2001.

Le français langue pluricentrique? Études sur la variation diatopique d'une langue standard. Frankfurt am Main: Peter Lang, 2005.

Vol. 25 - Ano $44-n^{\circ} 2-2020$ 
. Situaciones pluricéntricas en comparación: el español frente a otras lenguas pluricéntricas. In LEBSANFT, Franz; MIHATSCH, Wiltrud; POLZIN-HAUMANN, Claudia (eds.). El español, ¿desde las variedades a la lengua pluricéntrica? Madrid; Frankfurt am Main: Iberoamericana; Vervuert, 2012, p.29-46.

. Französisch außerhalb Frankreichs. Geschichte, Status und Profil regionaler und nationaler Varietäten. 2ªed. Berlin; Boston: De Gruyter, 2017.

POLO, José. Entorno del universo normativo de Eugenio Coseriu. Cuaderno de bitácora. Madrid: Editorial Biblioteca Nueva, 2012.

RABANALES, Ambrosio. ¿Qué es hablar correctamente? Revista de Educación, n.119, p.49-58, 1984.

RIVAROLA, José Luis. Sobre variedades y normas del español en el marco de una cultura lingüística pluricéntrica. In: Actas del II Congreso Internacional de la Lengua Española (Valladolid, 16-19 de octubre de 2001). Valladolid: Instituto Cervantes, 2001, p.1-15.

. El español en el siglo XXI: los desafíos del pluricentrismo. Boletín Hispánico Helvético, v.8, p.97-109, 2006.

SANTOS, Eduardo Ferreira dos. Aspectos da língua portuguesa em Angola. PAPIA, v.28(1), p.25-49, 2018.

SCHMIDT-REDEFELDT, Jürgen. Portugiesisch. In: JANICH, Nina; GREULE, Albrecht (orgs.). Sprachkulturen in Europa. Ein internationales Handbuch. Tübingen: Narr, 2002, p.211-219. SCHNEIDER, Edgar W. The Dynamics of New Englishes: From Identity Construction to Dialect Birth. Language, v.79, n.2, p.233-281, 2003.

SILVA, Augusto Soares. The cognitive approach to pluricentric languages and the pluricentricity of Portuguese: What's really new? In: MUHR, Rudolf (ed.). Pluricentric Languages and Non-Dominant Varieties Worldwide. Frankfurt am Main: Peter Lang, 2016, p.13-34.

. Modelos cognitivos da lusofonia. Romantismo e racionalismo nas políticas de língua e comunicação de unidade/diversidade do português europeu e brasileiro. In: MARTINS, Moisés (ed.). A Internacionalização das Comunidades Lusófonas e Ibero-Americanas de Ciências Sociais e Humanas - O Caso das Ciências da Comunicação. Famalicão: Edições Húmus, 2017, p.319-335.

O português no mundo e sua estandardização: entre a realidade de uma língua pluricêntrica e o desejo de uma língua internacional. In: BARROSO, Henrique (ed.). O Português na Casa do Mundo, Hoje. Braga: Edições Húmus, 2018a, p.111-132.

Variação linguística e pluricentrismo: novos conceitos e descrições. In: DÍAZ, Marta et al. (eds.). Actas do XIII Congreso Internacional de Lingüística Xeral. Vigo: Universidade de Vigo, 2018b, p.838-845. 
STEWART, William. A sociolinguistic typology for describing national multilingualism. In: FISCHMAN, Joshua (ed.). Readings in the sociology of language. The Hague; Paris: Mouton, 1968, p.531-546.

TARALLO, Fernando. Diagnosticando uma gramática brasileira: O português d'aquém e d'além-mar ao final do século XIX. In: ROBERTS, Ian; KATO, Mary (eds.). Português brasileiro: uma viagem diacrônica. São Paulo: UNESP, 1993, p.69-105.

TARP, Sven; GOUWS, Rufus. A Lexicographic Approach to Language Policy and Recommendations for Future Dictionaries. Lexikos, v.18, p.232-255, 2008.

. Skoolwoordeboeke virhuistaalleerders vanAfrikaans. Lexikos, v.20, p.466-494, 2010.

School dictionaries for first-language learners. Lexikos, v.22, p.333-351, 2012.

THOMPSON, Robert. Spanisch as a pluricentric language. In: CLYNE, Michael (ed.).

Pluricentric languages: Differing Norms in Different Nations. Berlin; New York: Mouton de Gruyter, 1992, p.45-71.

TRASK, Robert Lawrence. Dicionário de Linguagem e Lingüística. $2^{\mathrm{a}}$ ed. Tradução de Rodolfo Ilari. São Paulo: Contexto, 2006.

VERDELHO, Telmo. Lexicografia (Portugiesisch: Lexikographie). In: HOLTUS, Günter; METZELTIN, Michael; SCHMITT, Christian (eds.). Lexikon der romanistischen

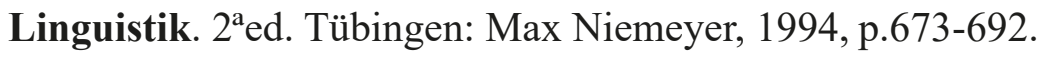

WELKER, HerbertAndreas. Dicionários. Uma pequena introdução à lexicografia. $2^{\mathrm{a}} \mathrm{ed}$. Brasília: Thesaurus, 2004.

O uso de dicionários. Brasília: Thesaurus, 2006a.

Breve histórico da metalexicografia no Brasil e dos dicionários gerais brasileiros. Matraga, v.13(19), p.69-84, 2006 b.

WIEGAND, Herbert Ernst. Nachdenken über Wörterbücher: Aktuelle Probleme. In: DROSDOWSKY, Günther (ed.). Nachdenken über Wörterbücher. Mannheim: Bibliographisches Institut, 1977, p.51-102.

ZANATTA, Flávia. Breve panorama da situação da norma lingüística no Brasil. Lusorama, v.77/78, p.79-102, 2009.

. A normatividade e seu reflexo em dicionários semasiológicos de língua portuguesa. Dissertação de Mestrado em Lexicografia e Terminologia. Porto Alegre: Universidade Federal do Rio Grande do Sul, Instituto de Letras, 2010.

ZANATTA, Flávia; BUGUEÑO MIRANDA, Félix. A normatividade nos dicionários gerais de língua portuguesa. In: LIMA-HERNANDES, Maria Célia et al. (orgs.). A língua portuguesa no mundo. São Paulo: Editora da FFLCH, 2007, p.1-20.

ZIMMERMANN, Klaus. Lexicografía diferencial y lexicografía integral. In: ÁLVAREZ DE LA GRANJA, María; GONZÁLEZ SEOANE, Ernesto (eds.). Léxico dialectal y lexicografía en la Iberorromania. Madrid; Frankfurt am Main: Iberoamericana; Vervuert, 2018, p.121-144. 